\title{
Chapter 8 \\ Bioremoval of Graffiti in the Context of Current Biocleaning Research
}

\author{
Pilar Bosch-Roig and Patricia Sanmartín
}

\begin{abstract}
Some microorganisms can be used as bioremediation agents, in biocleaning treatments, to remove undesired sulphates, nitrates and organic matter from cultural heritage surfaces. Graffiti materials (mainly spray paints) are now included in the list of materials that can be biocleaned, with studies on this topic being initiated just over 5 years ago. Research on the bioremoval of graffiti is continuing and on a promising track. This chapter reports a critical analysis of studies of the bioremoval of graffiti carried out in recent years, which are compared with similar studies of the removal of salts (mainly nitrates and sulphates) and organic matter conducted in the last thirty years. Likewise, the present challenges and ways of overcoming them are addressed towards developing a complete protocol for the use of bioremediation to remove graffiti, with particular emphasis on the use of the method for cleaning facades and buildings.
\end{abstract}

Keywords Bacterial strains $\cdot$ Biocleaning $\cdot$ Cultural heritage $\cdot$ Microbial agents Safe methods $\cdot$ Stone

\section{Introduction}

The use of naturally occurring bacteria, and to lesser extent fungi, in biocleaning treatments for cultural heritage buildings and monuments is currently popular and provides an effective, non-invasive, relatively ecologically safe and inexpensive approach to cultural heritage conservation (Bosch-Roig and Ranalli 2014; Sanmartín

\footnotetext{
P. Bosch-Roig $(\bowtie)$

Instituto Universitario de Restauración del Patrimonio, Universitat Politècnica de València,

Valencia, Spain

e-mail: mabosroi@upvnet.upv.es

P. Sanmartín

Departamento de Edafoloxía e Química Agrícola. Facultade de Farmacia, Universidade de

Santiago de Compostela, Santiago de Compostela, Spain

e-mail: patricia.sanmartin@usc.es
} 
et al. 2018). From the beginning of the 1990s until the present, viable (non-pathogenic) cells and selected enzymes have been identified and used for the biological removal of undesired substances, such as salts (mainly nitrates and sulphates) and organic matter from stone substrates (Webster and May 2006). In the last few years graffiti paint has been added to this list as an undesired, potentially bioremovable material. The inclusion of graffiti paint in this list arose as a result of the drawbacks and environmental impacts of the methods then available (chemical and physical, including laser) for graffiti removal (Sanmartín et al. 2014). A need to develop a new inexpensive, risk-free method, especially designed for use in porous materials (such as natural stone, cement and mortar lime) was also recognized (Sanmartín et al. 2014; Sanmartín and Bosch-Roig 2019).

Every year large amounts of money and effort are expended in removing disfiguring graffiti from urban fabric surfaces (Sanmartín et al. 2014, 2016). For example, in the early 2000 s about 20,000 private buildings and more than 400 municipal buildings in the city of Milan (Italy) were estimated to be disfigured every year (DDL 1607 2002). However, extrapolating the findings on bioremoval of salts and organic matter to graffiti is not an easy or direct task, and it is necessary to first identify microorganisms as potential candidates. In relation to the occurrence of microorganisms on paints, an earlier review paper concerning the biodeterioration of architectural paint by bacteria, fungi and algae indicated that studies on the microbial ecology of paints are scarce (Gaylarde et al. 2011). One study of painted walls in Latin America described microbial populations mainly formed by bacteria (including actinobacteria and cyanobacteria) as well as by populations of algae, protozoa, rotifers, nematodes and a huge variety of fungi (Gaylarde and Gaylarde 2000). The same authors also reported that biomass on external painted walls of buildings in Europe and Latin America is generally composed of fungi and to a lesser extent actinobacteria, which are more commonly found on building surfaces in Europe than in Latin America (Gaylarde and Gaylarde 2005). However, these results do not apply to other types of surfaces. Hence, some authors have reported that actinobacteria are commonly found on different types of damaged materials and buildings (e.g. ceramics and sandstone monuments) in Europe and on floor dust in damaged buildings in the USA (Hyvärinen et al. 2002; Palla et al. 2002; Macedo et al. 2009; Park et al. 2017). Allsopp et al. (2004) listed the fungi and phototrophs detected on paint films comprising refined and processed materials. Furthermore, in a review of several published studies on microbial colonization of frescoes and in regard to the presence of microorganisms and their role in damage to painted surfaces, Ciferri (1999) concluded that bacteria may be the first colonizers. After bacterial colonization chemically modifies some of the components of the paint and renders them utilizable, fungi may be able to become established and often become the principal microflora on painted surfaces (Ciferri 1999; Gaylarde et al. 2011). Whether or not they are the most abundant organisms, fungi have long been considered the major biodeteriogens in painted surfaces, producing paint-degrading metabolites (principally organic acids) that weaken and then penetrate the film (Grant et al. 1986). For example, during the 1950s, some researchers considered Aureobasidium pullulans (formerly Pullularia pullulans) to be the main biological agent involved in paint 
deterioration (Reynolds 1950; Klens and Lang 1956). Filamentous algae and actinobacteria can also alter painted surfaces by penetrating the paint film and releasing reactive metabolites that reduce the effectiveness and lifespan of the coating (Gaylarde et al. 2011). However, more recently, a study involving bioremediation processes showed that black fungi are not suitable for biocleaning stone artefacts, as they can damage stone treated with synthetic polymers (Troiano et al. 2014).

Most microorganisms found on paint films are actually aerial contaminants and are not involved in degradation processes (Gaylarde et al. 2011). More specifically, very few microorganisms have been shown to degrade graffiti. Indeed, in the only study to date of the microbial ecology of graffiti wall paintings, of a total of fifty-four different isolates, only nine bacterial isolates and one fungal isolate showed some capacity to degrade spray paint graffiti; of these, only three were isolated from recent or old graffiti (Sanmartín et al. 2016).

\section{Why Can Graffiti Paint Be Removed by Biocleaning Treatments?}

Graffiti spray paint contains the following main ingredients: (i) pigment, which provides colour, (ii) binding medium, in which the pigment particles are dispersed, and which hardens and binds the pigments on the painted surface and (iii) solvent, which allows the pigment/binder mixture to flow. Acrylic- and alkyd-based binders are common in current non-metallic graffiti formulations, while polyethylene-type binders predominate in metallic formulations. Semi-synthetic binders are also relatively common, although increasingly less so. Thus, although a study conducted about fifteen years ago showed that almost half of the varieties of red graffiti spray paint contain alkyd-nitrocellulose based binders (Govaert and Bernard 2004), these paints have been displaced by red alkyd paints.

Graffiti spray paints contain man-made compounds both as binders and as pigments, and they can therefore be considered xenobiotic (synthetic) substances. Although it is commonly thought that synthetic substances are more resistant to microbial attack than natural components, several studies have demonstrated the contrary (Cappitelli and Sorlini 2008; Troiano et al. 2014). Moreover, paint contains a wide variety of organic and inorganic biodegradable components, including additives such as emulsifiers, thickeners, etc., which may be utilized for growth by a large variety of microbial species (Ciferri 1999; Sanmartín et al. 2014). Most biodegradable substances, including graffiti paints, contain a mixture of carbon and elements such as oxygen, nitrogen, sulphur and phosphorus, which create charge imbalances that enzyme-containing bacteria can exploit. Thus, in previous studies, aged synthetic resins in outdoor environments (Cappitelli et al. 2007) and synthetic polymers in indoor environments (Lustrato et al. 2012) have been utilized by microorganisms as growth substrates. Likewise, cases have been reported wherein 
some microorganisms, such as fungi and particularly bacteria, can modify spray paint, even inside the cans (Bentley and Turner 1998). Microorganisms can enter the paint via infected raw materials (including water) or unsterile equipment. For example, the presence of bacteria has been found to cause reduced viscosity, gassing and colour drift in latex paint (Bentley and Turner 1998). In this regard, the components of spray paint affect microorganisms, either by inhibiting or stimulating their development. Thus, cellulose derivatives can act as nutrients for fungal cells (Allsopp et al. 2004), whereas organic solvents and heavy metals in pigments can adversely affect fungi (Gaylarde et al. 2011). Higher proportions of resin in gloss paint may also yield greater bioresistance (Gaylarde et al. 2011).

Paint pigments may also affect the bioremoval process. In a study of differently coloured acrylic paint, red paint was colonized more rapidly by microbes than blue paint, probably due to the presence of copper in the blue paint $(\approx 0.4 \%)$, which acts as a microbiocide (Breitbach et al. 2011). Zinc oxide can also act as an antimicrobial agent and has been found to exert fungicidal activity at a concentration of $2 \%$ in oil-based paint (Turner 1967). Antimicrobial compounds are added to liquid paint both to protect the paint in-can and to reduce fouling of the dry film. However, there is no universally active antimicrobial ingredient that is compatible with all paint formulations and that meets the requirements of the coating manufacturers. Thus, mixtures of antimicrobials are often used, among which isothiazolinone-based compounds are widely used for conserving paint (Gaylarde et al. 2011). In a study of 29 freshly dried synthetic resins used as paint binding media, almost all the acrylic resins proved to be resistant to fungal attack, while all alkyd resins and some polyvinyl acetates (PVAs) were found to be biodegradable (Cappitelli et al. 2005). These findings indicate that under favourable environmental conditions, and considering the same paint components, alkyd-based paint would be more readily biodegraded than acrylic-based paint. The authors of the aforementioned study also noted that knowledge of the microbial susceptibility of the binding medium under certain conditions does not necessarily enable prediction of the potential of a specific paint to undergo biodegradation. In fact, pigments and other components may be readily available sources of carbon in paint formulations.

\section{Methodological Advances in Bioremoval of Salts, Organic Matter and Graffiti}

Microorganisms have mainly been used to remove undesired inorganic salts (nitrates and sulphates) and organic substances (animal glue, casein, hydrocarbons, lipids, etc.) from inorganic surfaces (stone sculptures, building façades and frescoes). Few studies have been conducted in relation to the use of microorganisms to remove paints (included graffiti paints) produced in the twentieth and twenty-first centuries and which contain synthetic polymers. 
Bioremoval strategies have in common the following basic general steps: (i) identification of the substance to be cleaned and the original material to be protected; (ii) identification, selection and growth (selection of culture media and growth protocols) of suitable microorganisms (non-spore forming, non-pathogenic, not biodeteriogens); (iii) selection of on-site application protocols (with delivery systems compatible with microorganisms and artistic surface) and conditions (treatment time and temperature) for on-site application and (iv) establishment of longterm monitoring of biocleaned substrates (Fig. 8.1).

The first step is common to all restoration-conservation strategies, and extensive research has been conducted in regard to the use of sensitive and selective techniques for identifying organic materials (gas chromatography coupled with mass

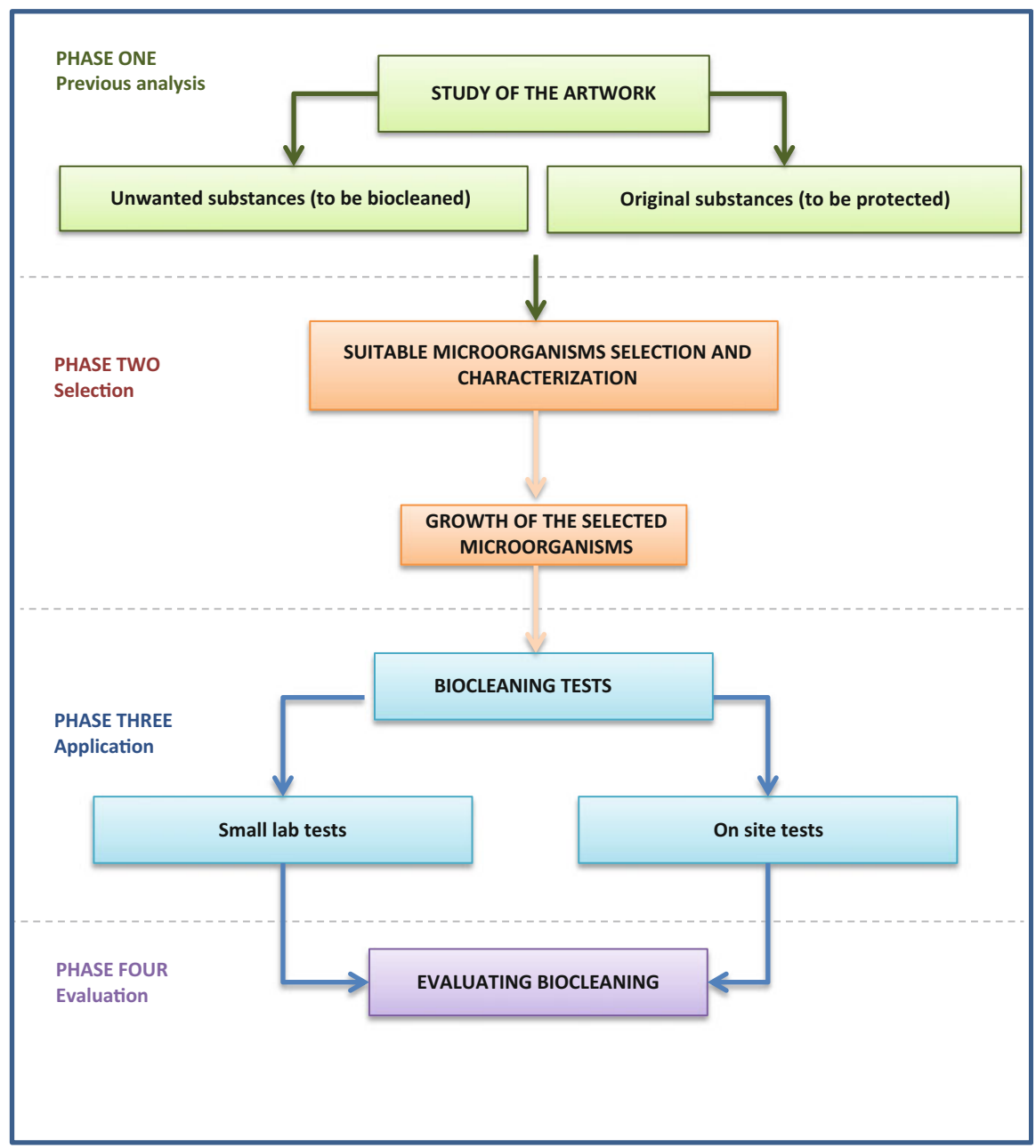

Fig. 8.1 General stages of biocleaning research 
spectrometry (GC-MS), pyrolysis-GC-MS and inorganic materials (FTIR, SEM, Ion-chromatography)) (Colombini et al. 1999, 2003; Ranalli et al. 2005; BoschRoig et al. 2013). As this first step is well known and used in the field of restoration, it is not considered in this chapter, which includes a comparison of the methodological analysis of the other three general steps involved in the bioremoval of salt and organic matter and of graffiti. The chapter also includes a critical analysis of the methodological advances made by the scientific community and the applicability of these in the field of graffiti removal (see Section 3 and Table 8.1).

\subsection{Selection of Suitable Microorganisms for the Bioremoval of Graffiti}

As relatively few studies have addressed the biodeterioration and biocleaning of graffiti, few microorganisms with the potential to degrade graffiti paint have been identified (Table 8.2). Therefore, focusing on the selection of suitable microorganisms is an important area of study. Candidate microorganisms can be found in international collections of microorganisms (DSMZ, ATCC, CECT, etc.) or in natural environments.

If researchers wish to use registered microorganisms, these should be selected for their particular characteristics and be purchased and assayed in the laboratory in order to evaluate their capacity to grow and degrade graffiti. Although this is a faster and probably cheaper selection method, some studies have shown that it is more difficult to obtain the most suitable microorganisms. Ranalli et al. (2005) conducted a comparative enzymatic analysis of the bioremoval capacity of a bacterium (Pseudomonas stutzeri A29) directly isolated from the substance to be removed (aged animal glue from frescoes) and compared with six other commercial strains of the same genera (Pseudomonas) and even species (P. stutzeri). This study revealed that all strains tested were able to synthesize inducible specific enzymes after being grown with the target substance (animal glue). However, the isolated strain (P. stutzeri A29) grew optimally and displayed the highest enzymatic (protease) activity (Ranalli et al. 2005). A study of the molecular mechanisms of action in this particular strain revealed a unique enzymatic profile when the bacterium was grown with the glue isolated from the fresco. The enzymes may be a mixture of particular proteases whose combined action enables the complete digestion of the hardened glue present in the frescoes (Antoniolli et al. 2005).

A logical starting point for obtaining microorganisms that can act as biocleaning agents from natural sources is to isolate them from the substance to be removed. This was done, for example, by analysing black crust biofilms, from which different researchers have isolated sulphate reducing bacteria (SRB), hydrocarbon degrading bacteria (HDB) and other microorganisms with hydrolytic activities able to degrade polycyclic aromatic hydrocarbons and fatty acids, among others (Saiz-Jimenez 1993, 1997; Fernandes 2006; Soffitti et al. 2019). In the case of graffiti paint, outdoor 


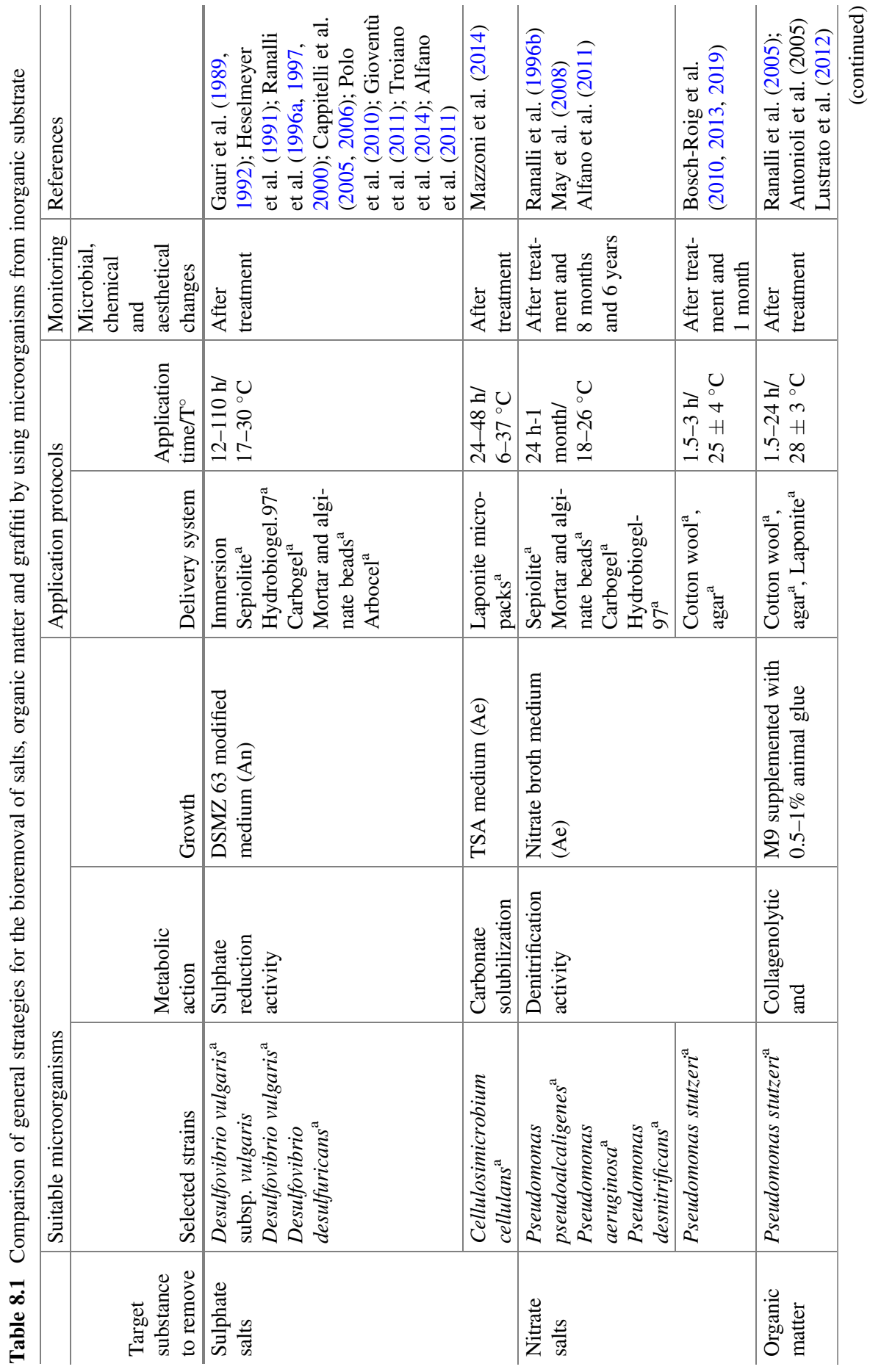




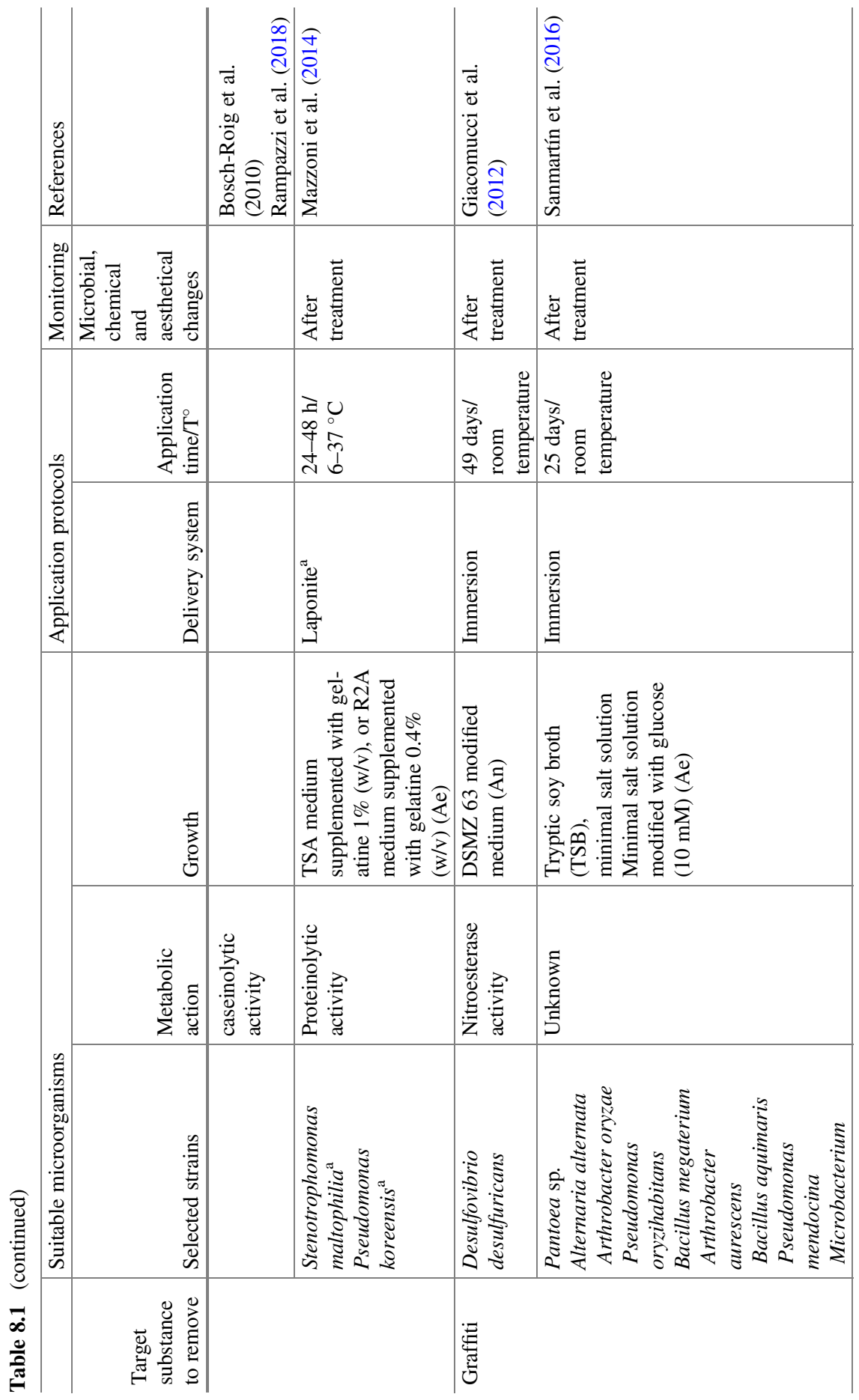




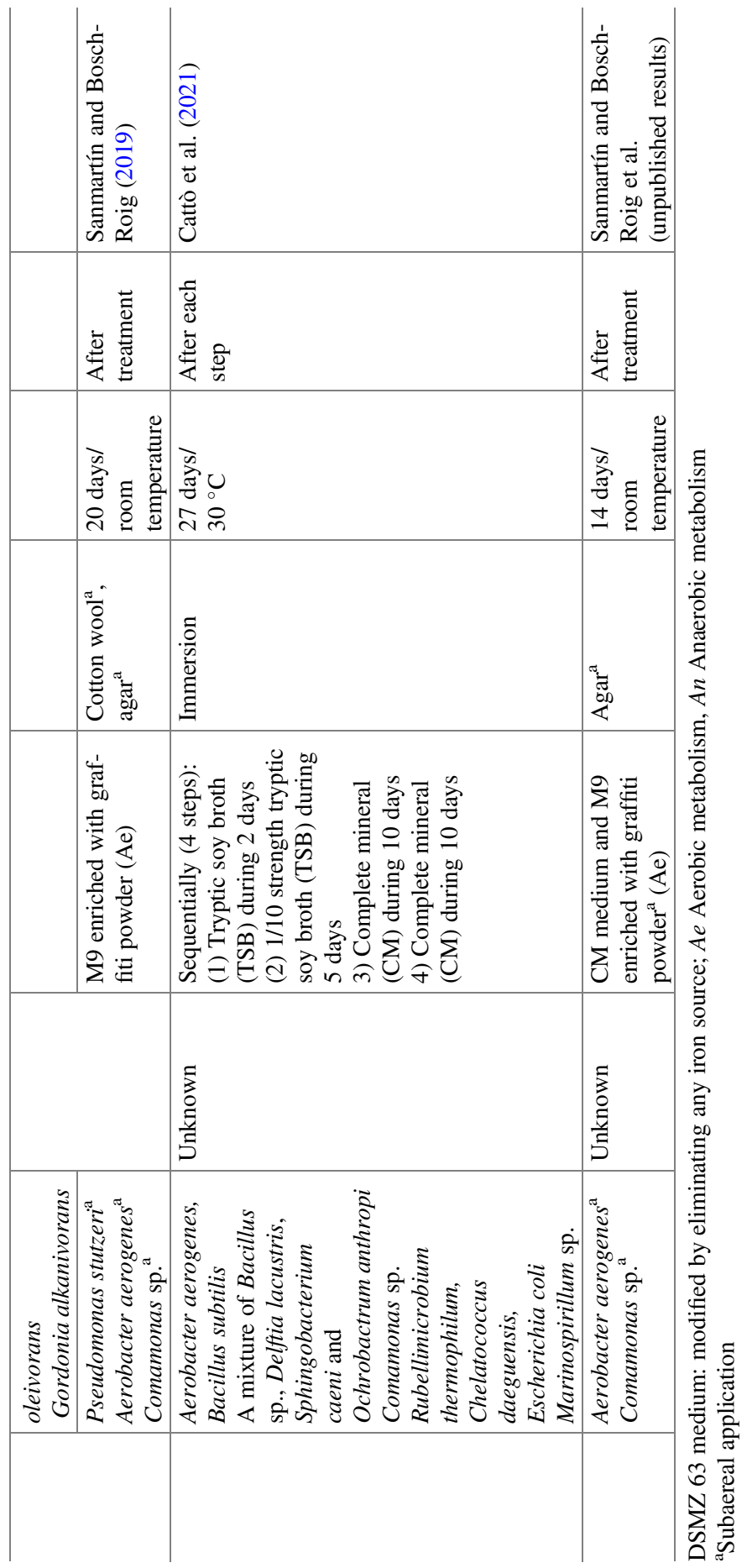




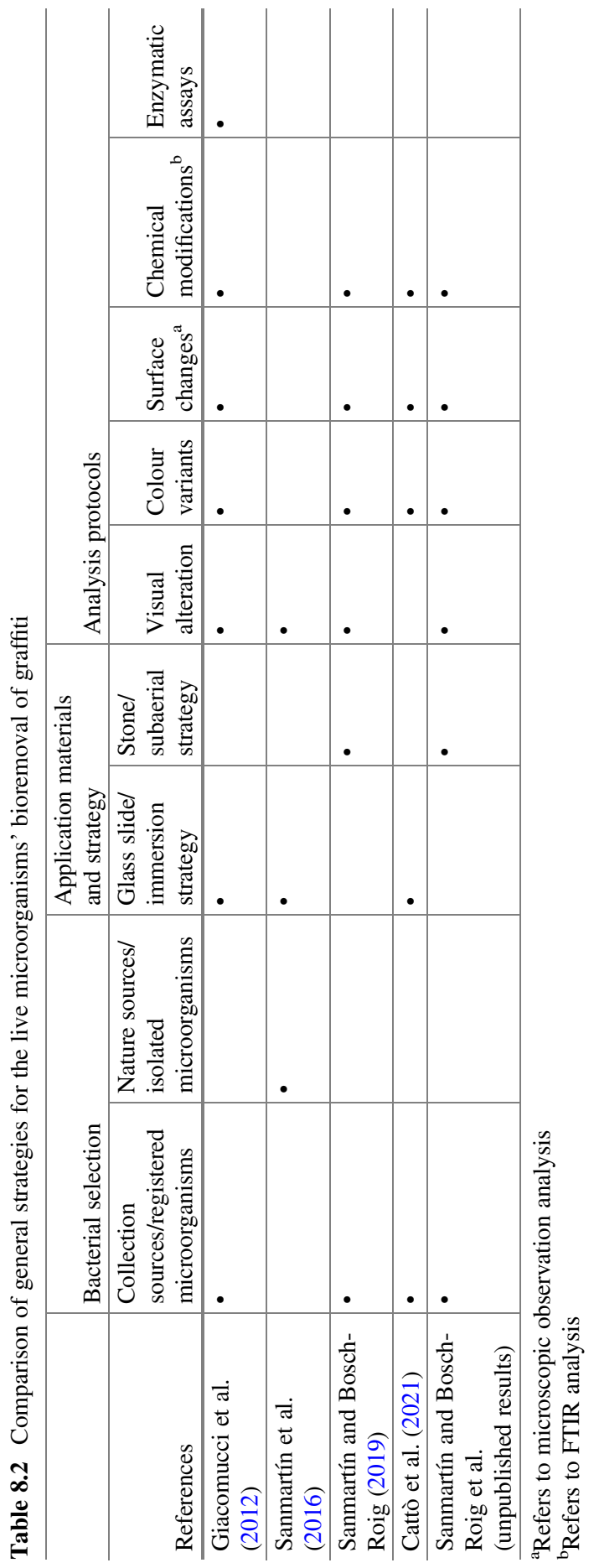


graffiti paintings and the inside of spray paint cans are candidate sources of microorganisms (Sanmartín et al. 2016). After selection of the natural sources to be analysed, the microbial content can be examined by one of the two different methods: (i) the use of culture-dependent techniques (isolation of cultivable microorganisms) or (ii) the use of culture-independent techniques (studying both cultivable and non-cultivable microorganisms).

The study of cultivable microorganisms is based on microbiological analysis involving isolation, growth and identification stages. Sampling can be done with sterile swabs moistened with sterile buffer solution or by contact plates with general culture media. Samples should then be cultivated in culture solid plates containing general culture media such as nutrient agar or nutrient broth (Fig. 8.2). Morphologically different colonies of microorganisms are then selected and sub-cultured to yield pure colonies. The pure colonies can be identified by classical morphological methods (by microscopic examination and dichotomous identification keys), biochemical tests (API tests, for example) and by sequencing methods based on the study of $16 \mathrm{~S}$ rDNA (for bacteria) and ITS or 18S rDNA (for fungi) gene sequences (DNA extraction and polymerase chain reaction [PCR]) (Polo et al. 2010). In the field of graffiti biocleaning, only one molecular biological approach has been used to

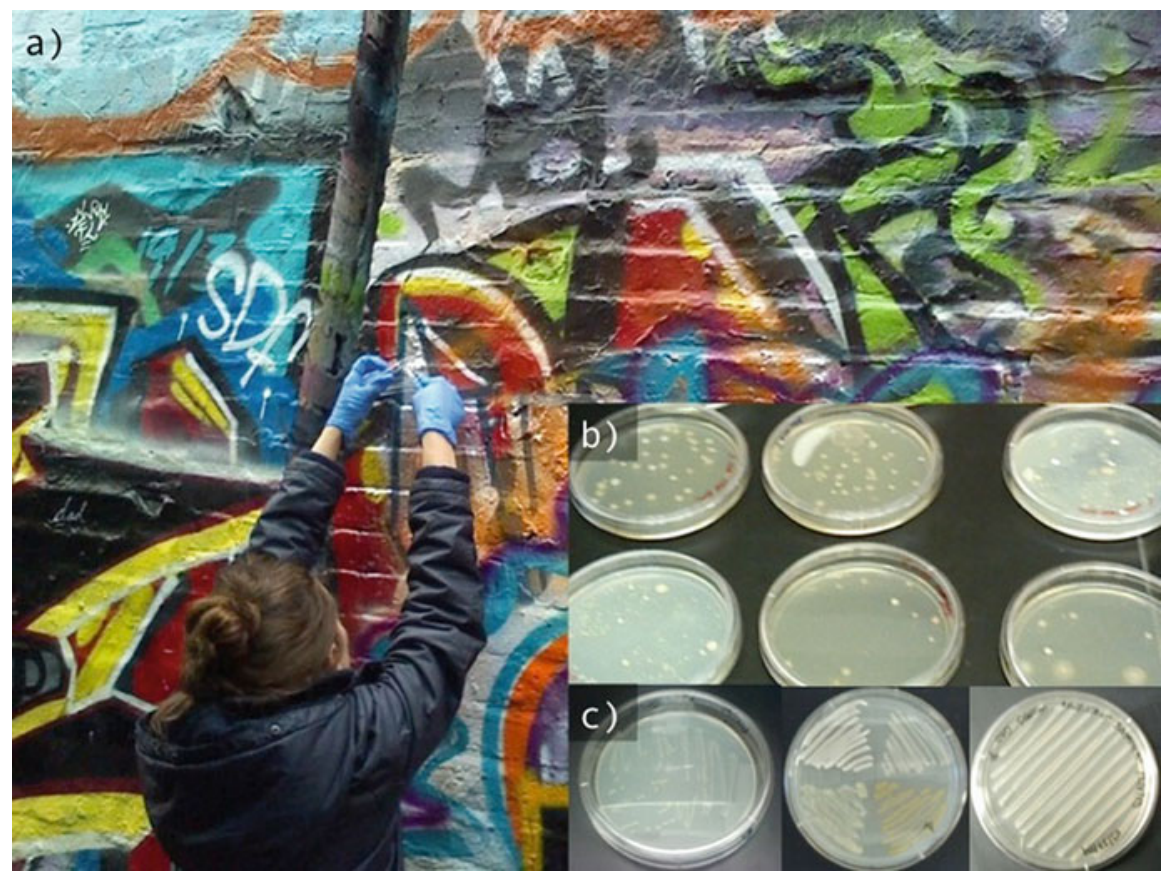

Fig. 8.2 (a) Sampling bacteria from new graffiti. (b) Example of plates initially used to screen for colonies found on graffiti and associated environments. (c) Different colonies of microorganisms selected, isolated and sub-cultured to test their potential use as graffiti removal agents. The images are reproduced from Sanmartín et al. (2016) 
identify microorganisms from natural sources: nine cultivable bacteria and one fungus were identified as candidates for biocleaning purposes by sequencing of 16S rDNA and fungal ITS regions (Sanmartín et al. 2016).

Traditional identification techniques are sometimes tedious and time consuming. Researchers are currently focusing on new methodological advances such as matrixassisted laser desorption ionization-time of flight mass spectrometry (MALDI-TOFMS) to identify cultivable microorganisms. This technique captures the molecules present in the microorganisms by detecting proteins, peptides and lipid ions. It identifies a bacterial spectrum, rather than specific DNA sequences. As the samples do not require pretreatment, the method is therefore more rapid than traditional identification techniques; in addition, no reagents are required, and more than 1000 samples can be analysed per day. For identification, the bacterial spectrum obtained must then be compared with the existing databases. The main limitation of this technique is that few of the databases available include environmental microorganisms, and that many of the existing ones are costly to access (Shingal et al. 2015).

Massive DNA sequencing represents another important methodological advance in the identification of microorganisms. This approach can be used to study cultivable and non-cultivable microorganisms isolated from natural samples because it enables direct sequencing of native DNA/RNA. This next generation sequencing (NGS) technique can provide a more complete view of the microbial communities associated with an object or substrate (Vilanova and Porcar 2020). New generation single molecule nanopore technology sequencing (MinION Oxford Nanopore Technologies) is emerging and can be used for the rapid, simple identification of microorganisms as potential biocleaning agents. The huge amounts of nucleotide sequence data must be analysed and compared with existing databases in order to identify the microorganisms. The advantages of this method are that the analysis of long sequences enables more precise identification, little material is needed and the experimental process is simplified. There is no need to grow the microorganisms or to extract or amplify DNA for sequencing (Feng et al. 2015). This method provides more comprehensive information about the microbial populations colonizing a particular substrate (e.g. graffiti) because it produces data on all the microorganisms present in the sample.

A combination of culture-dependent and culture-independent techniques should be used to identify and study microorganisms as potential graffiti biocleaning agents. After identification, the microorganisms must be grown/cultivated in a particular medium supplied with the target substance as a sole carbon source. The biodegradative capacities should then be analysed, among other factors, in order to finally apply them in practical biocleaning actions (Vilanova and Porcar 2020). 


\subsection{Culture Media and Growth Protocols for the Selected Microorganisms}

Once microorganisms have been purchased or isolated, they must be grown in the laboratory. The establishment of growth media and growth protocols is therefore an important methodological step to consider.

In order to use microorganisms for cleaning purposes, they must be grown in an enriched culture or minimal medium with the substrate to be degraded in order to adapt their metabolism for cleaning the substrate of interest. This is a basic biocleaning rule. For example, for removal of animal glue from frescoes, selected microorganisms were grown in the laboratory with culture media enriched with animal glue (Ranalli et al. 2005); for removal of black crust from stone materials, the selected microorganisms were grown with selected culture media enriched with sulphates (the principal component of black crusts), and for removal of salts from granite pavement stone, nitrate broth was used to grow the selected microorganisms (Bosch-Roig et al. 2019).

Following this principle, a culture media enriched with graffiti components is needed to optimally prepare/adapt the selected microorganisms for the bioremoval of graffiti. In this regard, a protocol for obtaining a minimal liquid medium (M9) enriched with powdered graffiti has recently been improved (Fig. 8.3). The established growth protocol and growth medium can help researchers to both evaluate and isolate potential new biocleaning agents and to produce large volumes of the selected microorganisms, which are required for future on-site applications (Sanmartín and Bosch-Roig 2019). On the basis of the findings of traditional microbiological sensitivity assays, a positive hydrolytic reaction will be manifested as a clear zone around the bacterial colony. Indeed, some authors have used solid media (containing calcium carbonate, phosphate and gypsum) to potentially isolate biocleaning microorganisms by the visual appearance of a halo around the colony

Fig. 8.3 Micrograph of particles of powdered graffiti surrounded by biofilm

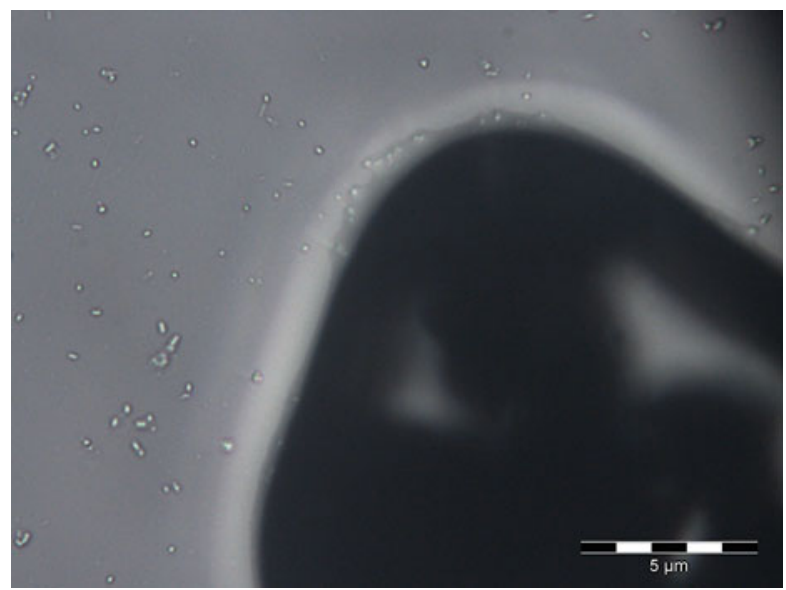


(Mazzoni et al. 2014). We are now focussing on adapting this isolation method in order to apply it to the isolation of microorganisms that could potentially be used for biocleaning graffiti. A new graffiti solid media rather than the liquid media currently used will facilitate the bacterial selection and evaluation process with visual results and prevent the need for a complementary analysis of graffiti degradation.

\subsection{Microorganism Application Protocols}

Another important aspect that should be considered in biocleaning strategies is that microorganisms require particular conditions (humidity and temperature) for growth. Therefore, different strategies have been used in the biocleaning field in order to improve application protocols (Bosch-Roig et al. 2015).

The first studies of bioremoval of graffiti used glass microscope slides painted with a graffiti layer. The microscope slides were placed in liquid cultures with the selected bacteria. Finally, the samples were incubated for long periods (25-49 days) (Giacomucci et al. 2012; Sanmartín et al. 2016). These initial studies were important because they showed that graffiti could be removed by biological means, although improvement of the application protocols was needed. The immersion protocol cannot be used for on-site graffiti biocleaning and therefore methodological advances were needed in this area. Based on the different delivery systems used in other biocleaning strategies, a more appropriate application protocol was developed by Sanmartín and Bosch-Roig (2019). This research has addressed this problem by studying two delivery systems commonly used in other biocleaning strategies: cotton wool and 2\% agar gel (Bosch-Roig et al. 2015). This research has produced interesting results for bioapplication on stone, contributing to the future transfer of the biocleaning technology to real, on-site stone graffiti removal. However, further work is required, because long treatment times are required, and the graffiti layer is not completely removed.

Another important factor associated with the application protocols is the temperature required for growth of the microorganisms. Most microorganisms used in biocleaning strategies are mesophilic, i.e. they grow optimally at moderate temperatures (between 20 and $45^{\circ} \mathrm{C}$ ). If biocleaning is carried out at temperatures lower than $20^{\circ} \mathrm{C}$ (very common in winter, for example), the effects could be altered or hampered. Different strategies (using air conditioning or heat lamps) could be used in order to reach the ideal temperature of the treatments (Ranalli et al. 2005; BoschRoig et al. 2013). However, some researches are focusing on the selection of microorganisms that can grow at higher temperatures. For example, Mazzoni et al. (2014) isolated biocleaning microorganisms (Stenotrophomonas maltophilia, Pseu-

domonas koreensis and Cellulosimicrobium cellulans), which have an optimal temperature range of $6-37^{\circ} \mathrm{C}$. 


\subsection{Protocols for Evaluating Graffiti Cleaning}

Once microorganisms have been purchased or isolated and grown under laboratory conditions, their hydrolytic abilities and metabolic capacities must be studied in order to determine how they will contribute to graffiti removal. Most biocleaning studies use one of the two approaches: (i) an indirect approach based on study of the degradation of the target substance (graffiti) or (ii) a more direct approach based on the study of the enzymes or proteins produced by the microorganisms.

Most studies have used the indirect strategy. Few studies have investigated the enzymes and proteins produced by the microorganisms. Physico-chemical analysis is usually used for this purpose.

Considering the field of graffiti biocleaning, all the studies conducted to date have used the indirect strategy, in which microorganisms are grown with the graffiti and the graffiti is then examined in terms of visual alteration, colour variations (by reflectance colour measurements), surface change (by stereomicroscope, epifluorescence microscope and electron microscope observations) and chemical modifications, using Fourier transform infrared spectroscopy (FTIR) (Giacomucci et al. 2012; Sanmartín et al. 2016; Sanmartín and Bosch-Roig 2019) (see Table 8.2). In particular, preliminary FTIR findings on the potential biodegradation pathways induced by Desulfovibrio desulfuricans in nitrocellulose-based paints have been reported (Giacomucci et al. 2012). These findings include a depletion of signal related to the $\mathrm{N}-\mathrm{O}$ bond, suggesting that the bacteria induce degradation of the paint via ammonification. In addition, Sanmartín and Bosch-Roig (2019)) have demonstrated bacterially induced chemical changes in graffiti paints, by using FTIR analysis. In the resulting spectra a decreasing intensity of peak bands related to alkanes, carbonyl, carbon-carbon triple bound and esters was observed. These types of indirect analysis could be complemented with other analytical strategies used in other graffiti cleaning strategies such as advanced laser-based techniques (laser-induced breakdown spectroscopy: LIBS), X-ray diffraction or RAMAN analysis (Gómez et al. 2010; Siano et al. 2012; Penide et al. 2013, Sanmartín et al. 2016).

More direct approaches based on enzymatic and proteomic analysis can also be used. In these approaches, microorganisms are grown with the target substance (graffiti) and the enzymatic activity or enzyme-protein production is then determined. In graffiti biocleaning, only one of these more direct approaches has been reported. In this study, the nitroesterase activity (nitrate and nitrite reductase activity) of a particular bacterial culture (Desulfovibrio desulfuricans) was evaluated by analysis of the presence of nitrate, nitrite and ammonia by use of a particular reagent that produces a colorimetric reaction (when the enzyme is expressed), which is then measured by spectrophotometry. This analysis enabled the researchers to conclude that $D$. desulfuricans was able to degrade the nitrocellulose present in paint binders, possibly by an ammonification pathway (Giacomucci et al. 2012).

In the field of biocleaning research, this type of direct analysis should inspire further studies on graffiti bioremoval. Enzymatic activity has been analysed by using biochemical (API-ZYMTM Systems BioMérieux, Rome, Italy) and colorimetric tests 
(based on azo dye impregnated casein) and (casein) zymograms (spectrophotometric assay) to evaluate and observe the enzymatic (protease) activity, in particular the specific caseinolytic and collagenolytic activity of the bacterium P. stutzeri A29 (Ranalli et al. 2005; Antonioli et al. 2005). Sulphate reducing activity has been evaluated in liquid culture medium by determining the residual sulphate content in the cultural broth medium by spectrophotometry (absorbance at $515 \mathrm{~nm}$ ) (Ranalli et al. 1997). Some authors have used colorimetric test strips that enable the rapid semi-quantitative evaluation of bacterial enzymatic activities. For example, nitrate and nitrite test strips can be used to analyse the optimal effectiveness of different bacterial strains for nitrate removal (Bosch-Roig et al. 2013).

The protein content of bacteria can be extracted and analysed by different methods. For example, Giacomucci et al. (2012) used ultrasound-assisted extraction and the Bradford method (based on the protein interaction to Coomassie dye under acidic conditions resulting in a colour change from brown to blue) to determine the total protein content of $D$. desulfuricans.

Advanced phenotypic technologies, such as phenotype microarray systems (PM Biolog system), can also be used to obtain information about the properties of the selected strains. These systems enable rapid screening of an extensive range of growth conditions (Borglin et al. 2012). Analysis of the use of almost hundred different carbon sources by a selected microorganism can be done simultaneously (96 well microplate), to produce a "metabolic fingerprint". This type of technology has been used to study carbon and nitrogen metabolism, chemical sensitivity (osmolyte tolerance, $\mathrm{pH}$ tolerance and toxic compound tolerance) and the metabolic pathways sustaining the biocleaning capacity of strain P. stutzeri DSMZ 5190, which has been widely used for biocleaning purposes (Bosch-Roig et al. 2016).

The so-called omic techniques are increasingly used in the field of conservation and restoration research. These techniques enable complete analysis of the total pool of DNA (genomics), the total proteins (proteomics) and their metabolites (metabolomics) (Vilanova and Porcar 2020).

\subsection{Long-Term Monitoring to Evaluate Graffiti Cleaning}

The final step that should be considered in any biocleaning process, especially in the treatment of decorative surfaces, is to monitor the changes on the cleaned surface over time (Bosch-Roig and Ranalli 2014). Monitoring must focus on at least two aspects: (i) the absence of microbial growth on the surface (microbial monitoring) and (ii) the absence of aesthetic alteration of the cleaned surface over time.

All graffiti biocleaning studies include both of these monitoring strategies after the cleaning, but further long-term changes must be still determined. However, diverse biocleaning studies have focused on the changes on the cleaned surface over time. For example, in Matera cathedral, the effects of nitrate bioremoval were monitored 8 months and 6 years after the treatment. In the areas treated with bacteria, the nitrate concentration remained stable, and no notable differences in microflora or 
colour changes were observed in comparison with an untreated control area (Alfano et al. 2011). Most biocleaning studies include aesthetic and microbiological monitoring (by plate count method, ATP determination and SEM observation, colorimetric analysis) immediately after and/or one month after the treatment. However, some studies have also undertaken long-term monitoring (1, 2, 6 and 12 months after the treatment), revealing the absence of residual cells on the treated surface and no colour changes in the treated areas (Lustrato et al. 2012; Bosch-Roig et al. 2013; Ranalli et al. 2018, 2019).

Methodological advances in long-term monitoring are required in graffiti biocleaning, and recent interest focuses on non-invasive techniques. Digital image analysis tools can be used for this purpose. This type of analysis has recently been used for the first time to analyse a surface after a biocleaning treatment (Bosch-Roig et al. 2019).

\section{Remaining Challenges in Graffiti Biocleaning}

According to the general stages described in this chapter, one important remaining challenge in graffiti biocleaning is to reduce the treatment application times.

Graffiti biodegradation application times of up to 49 days for Desulfovibrio desulfuricans ATCC 13541 applied under anaerobic conditions to red alkydnitrocellulose-based binder spray paint have been reported (Giacomucci et al. 2012). The same authors reported aerobic treatment requiring an application time of 27 days when Klebsiella aerogenes ATCC 13048, ATCC 53922 (mixed culture of Bacillus sp., Delftia lacustris, Sphingobacterium caeni and Ochrobactrum anthropi) and Comamonas sp. ATCC 700440 were used (Giacomucci et al. 2012). This was reduced to 25 days when aerobic microorganisms (Arthrobacter, Bacillus, Gordonia, Microbacterium, Pantoea, Pseudomonas and Alternaria) were used to remove black paint (alkyd and polyester resins or varnishes) (Sanmartín et al. 2016). Important improvements have also been made towards developing a feasible on-site method, reducing the application time to 20 days in a subaerial strategy (placing the strains onto spraying graffiti paint on stone material in an aerial environment, i.e. suitable for on-site conditions) (Sanmartín and Bosch-Roig 2019).

As indicated above, until now bioremoval of graffiti has been a slow process, and the first signs of deterioration of the paint take some time to appear. Sanmartín and Pozo-Antonio (2020) have recently addressed this challenge, suggesting that prior photodegradation of the paints may improve the bioremoval treatment in terms of application time, cleaning efficiency and economy. The study evaluated the weathering of graffiti spray paint on building stones exposed to different types of UV radiation (daylight, UV-A, UV-B and UV-C) and considered a combination of UV irradiation and biological treatment for graffiti removal.

According to popular belief, graffiti should be removed promptly, as the paint is generally considered to become more difficult to remove over time (see, e.g. Weaver 1995). However, a study of accelerated ageing of graffiti paints applied to stone was 
the first to demonstrate that the age of graffiti (i.e. the time that the graffiti has remained on the lithic substrate) enhances the effectiveness of the cleaning process (Sanmartín and Cappitelli 2017). This finding was strengthened in subsequent studies involving the removal of graffiti from anti-graffiti surfaces, in which the same conclusion was reached, in contrast to conventional wisdom (Pozo-Antonio et al. 2018).

Another (parallel) strategy is to identify the microorganisms that are the most efficient graffiti bioremoval agents. This approach should be accompanied by study of the enzymatic reactions involved in graffiti bioremoval to better elucidate the metabolic pathways. On-site, large-scale production of microorganisms is another remaining challenge that modern biotechnologies could help to solve (Philip and Atlas 2017).

Another challenge is the study of biocleaning strategies for diverse materials and graffiti colours and types. To date, only four substrates have been analysed: glass, natural granite stone, man-made concrete stone and metal (Fig. 8.4). In addition, only three types of graffiti have been tested: red spray paint (Motip-Dupli@̈

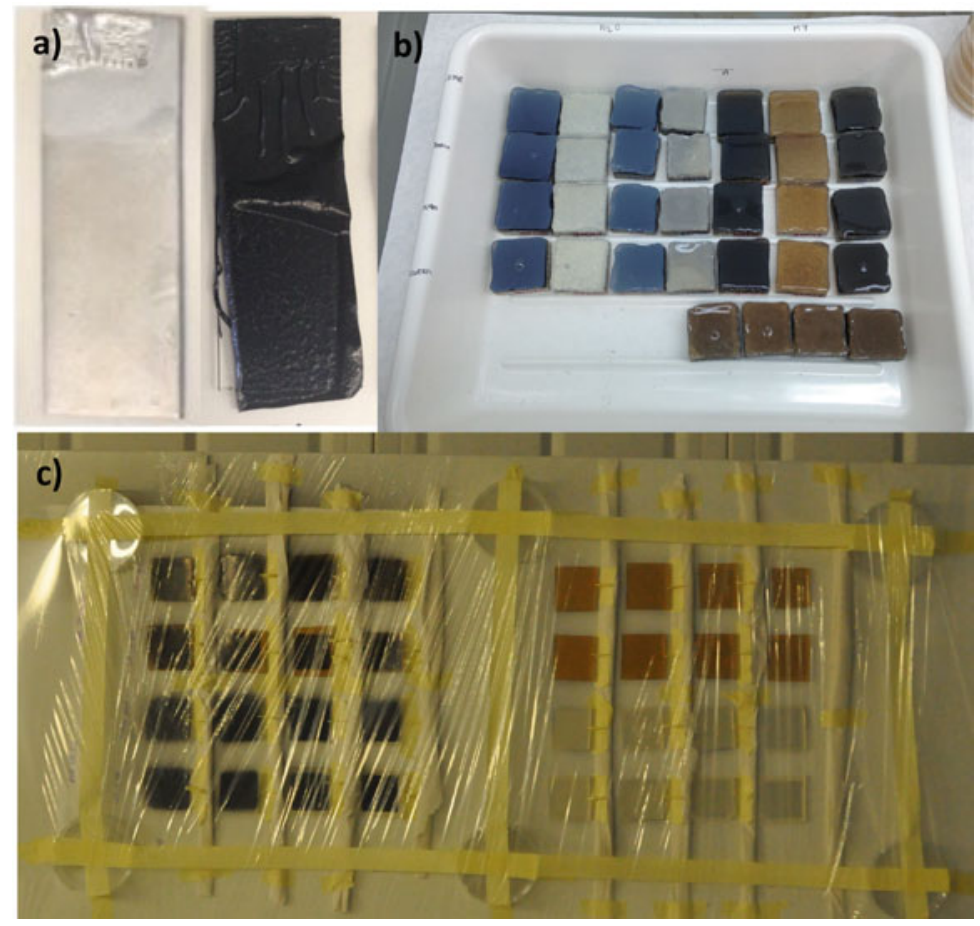

Fig. 8.4 Laboratory-based graffiti bioremoval from diverse materials and involving coloured paints. (a) Remains of black and silver graffiti on glass after immersion biocleaning. (b) Natural granite stone and man-made concrete stone painted with black and silver graffiti paint during agarassisted biocleaning. (c) Vertical metal sheet painted with black and silver graffiti paint during agarassisted biocleaning. The image is reproduced from Sanmartín and Bosch-Roig (2019) 
Autocolor, colour 5-0200), black non-metallic spray paint ( $R$-9011 from Montana Colors, Barcelona, Spain) and a silver metallic spray paint (Silver Chrome from Montana Colors).

Several authors have suggested that future research should focus on the following: (i) selection/identification of new biological formulation to effectively remove all kinds of paints and colours; (ii) the biocleaning potential of viable yeast cells (which produce few toxic metabolites); (iii) evaluation of the effectiveness of the cleaning of aged graffiti from different substrates; (iv) incomplete graffiti cleaning; (v) testing diverse delivery systems to shorten the biocleaning treatment times and resolve difficulties in application (Troiano et al. 2014; Gomes et al. 2017; Sanmartín and Bosch-Roig 2019).

\section{Conclusion and Final Remarks}

The bioremoval of graffiti is a promising green approach and risk-free method based on the use of selected microorganisms as "probiotics" (Cappitelli 2016; Sanmartín et al. 2016; Vilanova and Porcar 2020). However, it remains an emerging field in which there are still many challenges to be addressed and solved.

In this chapter, a comprehensive analysis has been conducted by focusing on comparing existing studies on the bioremoval of salts and organic matter by the use of live microorganisms in laboratory simulations or applied to real artwork. Special emphasis has been placed on the methodological advances made and on existing methodological tools and approaches used in related fields that could be applied in this particular area in order to help researchers address the remaining challenges.

Acknowledgements P. Sanmartín is grateful for financial support from the Xunta de Galicia (grant ED431C 2018/32).

\section{References}

Alfano G, Lustrato G, Belli C, Zanardini E, Cappitelli F, Mello E, Sorlini C, Ranalli G (2011) The bioremoval of nitrate and sulfate alterations on artistic stonework: the case study of Matera Cathedral after six years from the treatment. Int Biodeterior Biodegrad 65(7):1004-1011

Allsopp D, Seal K, Gaylarde C (2004) Introduction to biodeterioration. Chapter 3. Biodeterioration of refined and processed materials: paints, 2nd edn. Cambridge University Press, Cambridge, pp $78-85$

Antonioli P, Zapparoli G, Abbruscato P, Sorlini C, Ranalli G, Righetti PG (2005) Art-loving bugs: the resurrection of Spinello Aretino from Pisa's cemetery. Proteomics 5:2453-2459

Bentley J, Turner GPA (1998) Introduction to paint chemistry and principles of paint technology, 4th edn. Chapman \& Hall, London

Borglin S, Joyner D, DeAngelis KM, Khudyakov J, D’haeseleer P, Joachimiak MP, Hazen T (2012) Application of phenotypic microarrays to environmental microbiology. Curr Opin Biotechnol 23:41-48 
Bosch-Roig P, Regidor-Ros JL, Soriano-Sancho P, Doménech-Carbó MT, Montes-Estelles RM (2010) Ensayos de biolimpieza con bacterias en pinturas murales. Arché 4-5:115-124

Bosch-Roig P, Regidor-Rosi JL, Montes-Estellés RM (2013) Biocleaning of nitrate alterations on wall paintings by Pseudomonas stutzeri. Int Biodeter Biodegr 84:266-274

Bosch-Roig P, Ranalli G (2014) The safety of biocleaning technologies for cultural heritage. Front Microbiol 5:155

Bosch-Roig P, Lustrato G, Zanardini E, Ranalli G (2015) Biocleaning of cultural heritage stone surfaces and frescoes: which delivery system can be the most appropriate? Ann Microbiol 65:1227-1241

Bosch-Roig P, Decorosi F, Giovannetti L, Ranalli G, Viti C (2016) Connecting phenome to genome in Pseudomonas stutzeri 5190: an artwork biocleaning bacterium. Res Microbiol 167:757-765

Bosch-Roig P, Allegue H, Bosch I (2019) Granite pavement nitrate desalination: traditional methods vs. biocleaning methods. Sustainability 19:4227

Breitbach AM, Rocha JC, Gaylarde CC (2011) Influence of pigments on biodeterioration of paint films. J Coating Technol Res 8:619-628

Cappitelli F (2016) Biocleaning of cultural heritage surfaces. Open Conf Proc J 7(suppl 1: M6):65-69

Cappitelli F, Sorlini C (2008) Microorganisms attack synthetic polymers in items representing our cultural heritage. Appl Environ Microbiol 74:564-569

Cappitelli F, Vicini S, Piaggio P, Abbruscato P, Princi E, Casadevall A, Nosanchuk JD, Zanardini E (2005) Investigation of fungal deterioration of synthetic paint binders using vibrational spectroscopic techniques. Macromol Biosci 5:49-57

Cappitelli F, Zanardini E, Ranalli G, Mello E, Daffonchio D, Sorlini C (2006) Improved methodology for bioremoval of black crusts on historical stone artworks by use of sulfate-reducing bacteria. Appl Environ Microbiol 72:3733-3737

Cappitelli F, Nosanchuk JD, Casadevall A, Toniolo L, Brusetti L, Florio S, Principi P, Borin S, Sorlini C (2007) Synthetic consolidants attacked by melanine producing fungi: case study of the biodeterioration of Milan (Italy) Cathedral marble treated with acrylics. Appl Environ Microbiol 73:271-277

Cattò C, Sanmartín P, Gulotta D, Troiano F, Cappitelli F (2021) Bioremoval of graffiti using novel commercial strains of bacteria. Sci Total Environ 756:144075

Colombini MP, Modugno F, Giacomelli A (1999) Two procedures for suppressing interference from inorganic pigments in analysis by gas chromatography-mass spectrometry of proteinaceous binders in painting. J Chromatogr Acta 846:101-111

Colombini MP, Bonaduce I (2003) Gas chromatography/mass spectrometry for the characterization of organic materials in frescoes of the Monumental Cemetery of Pisa (Italy). Rapid Commun Mass Spectrom 17:2523-2527

Ciferri O (1999) Microbial degradation of paintings. Appl Environ Microbiol 65:879-885

DDL 1607 del 16 luglio (2002) Disciplina del fenomeno del "graffitismo". Annunciato nella seduta ant. n. 214 del 17 luglio 2002. (In Italian)

Feng Y, Zhang Y, Ying C, Wang D, Du C (2015) Nanopore-based Fourth-generation DNA sequencing technology. Genom Proteom Bioinf 13:4-16

Fernandes P (2006) Applied microbiology and biotechnology in the conservation of stone cultural heritage materials. Appl Microbiol Biotechnol 73:291-296

Gauri KL, Chowdhury AN, Kulshreshtha NP, Punuru AR (1989) The sulfation of marble and the treatment of gypsum crusts. Stud Conserv 34:201-206

Gauri KL, Parks L, Jaynes J, Atlas R (1992) Removal of sulfated-crusts from marble using sulphatereducing bacteria. In: Webster RGM (ed) Proceedings of the International Conference on Stone Cleaning and the Nature, soiling and decay mechanisms of stone. Donhead, Edinburgh, pp 160165

Gaylarde PM, Gaylarde CC (2000) Algae and cyanobacteria on painted buildings in Latin America. Int Biodeter Biodegr 46:93-97 
Gaylarde CC, Gaylarde PM (2005) A comparative study of the major microbial biomass of biofilms on exteriors of buildings in Europe and Latin America. Int Biodeter Biodegr 55:131-139

Gaylarde CC, Morton LHG, Loh K, Shirakawa MA (2011) Biodeterioration of external architectural paint films - a review. Int Biodeter Biodegr 65:1189-1198

Giacomucci L, Toja F, Sanmartín P, Toniolo L, Prieto B, Villa F, Cappitelli F (2012) Degradation of nitrocellulose-based paint by Desulfovibrio desulfuricans ATCC 13541. Biodegradation 23:705-716

Gioventù E, Lorenzi PF, Villa F, Sorlini C, Rizzi M, Cagnini A, Griffo A, Cappitelli F (2011) Comparing the bioremoval of black crusts on colored artistic lithotypes of the cathedral of Florence with chemical and laser treatment. Int Biodeterior Biodegrad 65:832-839

Gomes V, Dionísio A, Pozo-Antonio JS (2017) Conservation strategies against graffiti vandalism on cultural heritage stones: Protective coatings and cleaning methods. Prog Org Coat 113:90-109

Gómez C, Costela A, García-Moreno I, Sastre R (2010) Comparative study between IR and UV laser radiation applied to the removal of graffitis on urban buildings. Appl Surf Sci 252:2782-2793

Govaert F, Bernard M (2004) Discriminating red spray paints by optical microscopy, Fourier transform infrared spectroscopy and X-ray fluorescence. Forensic Sci Int 140:61-70

Grant C, Bravery AF, Springle WR, Worley W (1986) Evaluation of fungicidal paints. Int Biodegr 22:179-194

Heselmeyer K, Fischer U, Krumbein WE, Warsheid T (1991) Application of Desulfovibrio vulgaris for the bioconversion of rock gypsum crusts into calcite. Bioforum 1:89

Hyvärinen A, Meklin T, Vepsáläinen A, Nevalainen A (2002) Fungi and actinobacteria in moisturedamaged building materials-concentrations and diversity. Int Biodeter Biodegr 49:27-37

Klens PF, Lang JR (1956) Microbiological factors in paint preservation. J Oil Colour Chemists' Assoc 38:887-899

Lustrato G, Alfano G, Andreotti A, Colombini MP, Ranalli G (2012) Fast biocleaning of mediaeval frescoes using viable bacterial cells. Int Biodeter Biodegr 69:51-61

Macedo MF, Miller AZ, Dionísio A, Saiz-Jimenez C (2009) Biodiversity of cyanobacteria and green algae on monuments in the Mediterranean Basin: an overview. Microbiology $155: 3476-3490$

May E, Webster AM, Inkpen R, Zamarreño D, Kuever J, Rudolph C, Warscheid T, Sorlini C, Cappitelli F, Zanardini E, Ranalli G, Krage L, Vgenopoulos A, Katsinis D, Mello E, Malagodi M (2008) The BIOBRUSH project for bioremediation of heritage stone. In: May E, Jones M, Mitchell J (eds) Heritage microbiology and science: microbes, monuments and maritime materials. RSC Publishing, Cambridge, pp 76-93

Mazzoni M, Alisi C, Tasso F, Cecchini A, Marconi P, Sprocati AR (2014) Laponite micro-packs for the selective cleaning of multiple coherent deposits on wall paintings: the case study of Casina Farnese on the Palatine Hill (Rome-Italy). Int Biodeter Biodegr 94:1-11

Palla F, Federico C, Russo R, Anello L (2002) Identification of Nocardia restricta in biodegraded sandstone monuments by PCR and nested-PCR DNA amplification. FEMS Microbiol Ecol 39:85-89

Park JH, Cox-Ganser LM, White SK, Laney AS, Caulfield SM, Turner WA, Summer AD, Kreiss K (2017) Bacteria in a water-damaged building: associations of actinomycetes and non-tuberculous mycobacteria with respiratory health in occupants. Indoor Air 27:24-33

Penide J, Quintero F, Riveiro A, Sánchez-Castillo A, Comesaña R, del Val J, Lusquiños F, Pou J (2013) Removal of graffiti from quarry stone by high power diode laser. Opt Laser Eng 51: 64-370.

Philip J, Atlas R (2017) Chapter 4 - microbial resources for global sustainability. In: Microbial resources from functional existence in nature to applications. Ipek Kurtböke, Elsevier, Amsterdam, Netherland, pp 77-101 
Polo A, Cappitelli F, Brusetti L, Principi P, Villa F, Giacomucci L, Ranalli G, Sorlini C (2010) Feasibility of removing surface deposits on stone using biological and chemical remediation methods. Microb Ecol 60:1-14

Pozo-Antonio JS, Rivas T, Jacobs RMJ, Viles HA, Carmona-Quiroga PM (2018) Effectiveness of commercial anti-graffiti treatments in two granites of different texture and mineralogy. Prog Org Coat $116: 70-82$

Ranalli G, Chiavarini M, Guidetti V, Marsala F, Matteini M, Zanardini E, Sorlini C (1997) The use of microorganisms for the removal of sulphates on artistic stoneworks. Int Biodeter Biodegr 40:255-261

Ranalli G, Chiavarini M, Guidetti V, Marsala F, Matteini M, Zanardini E, Sorlini C (1996a) Utilisation of microorganisms for the removal of sulphates on artistic stoneworks. 3rd Int Biodeterior Biodegrad Symposium, Sociedad Española de Microbiología, Santiago de Compostela, pp 59-60

Ranalli G, Chiavarini M, Guidetti V, Marsala F, Matteini M, Zanardini E, Sorlini C (1996b) The use of microorganisms for the removal of nitrates and organic substances on artistic stone works. In: Riederer J (ed) Proceedings of the eighth International Congress of Deterioration and Conservation of Stone. Möller, Berlin, pp 1415-1420

Ranalli G, Matteini M, Tosini I, Zanardini E, Sorlini C (2000) Bioremediation of cultural heritage: Removal of sulphates, nitrates and organic substances. In: Ciferri O, Tiano P, Mastromei G (eds) Of microbes and art - the role of microbial communities in the degradation and protection of cultural heritage. Kluwer Academic-Plenum Publisher, pp 231-245

Ranalli G, Alfano G, Belli C, Lustrato G, Colombini MP, Bonaduce I, Zanardini E, Abbruscato P, Cappitelli F, Sorlini C (2005) Biotechnology applied to cultural heritage: biorestoration of frescoes using viable bacterial cells and enzymes. J Appl Microbiol 98:73-83

Ranalli G, Zanardini E, Andreotti A, Colombini MP, Corti C, Bosch-Roig P, De Nuntiis P, Lustrato G, Mandrioli P, Rampazzi L, Giantomassi C, Zari D (2018) Hi-tech restoration by two-steps biocleaning process of triumph of death fresco at the Camposanto Monumental Cemetery (Pisa, Italy). J Appl Microbiol 125:800-812

Ranalli G, Zanardini E, Rampazzi L, Corti C, Andreotti A, Colombini MP, Bosch-Roig P, Lustrato G, Giantomassi C, Zari D, Virilli P (2019) Onsite advanced biocleaning system for historical wall paintings using new agar-gauze bacteria gel. J Appl Microbiol 126:1785-1796

Rampazzi L, Andreotti A, Bressan M, Colombini MP, Corti C, Cuzman O, d'Alessandro N, Liberatore PL, Raimondi V, Sacchi B, Tiano P, Tonucci L, Vettori S, Zanardini E, Ranalli G (2018) An interdisciplinary approach to a knowledge-based restoration: the dark T alteration on Matera Cathedral (Italy). Appl Surf Sci 458:529-539

Reynolds ES (1950) Pullularia as a cause of deterioration of paint and plastic surfaces in South Florida. Mycologia 42:432-448

Saiz-Jimenez C (1993) Deposition of airborne organic pollutants on historic buildings. Atmos Environ 27B:77-85

Saiz-Jimenez C (1997) Biodeterioration vs biodegradation: the role of microorganisms in the removal of pollutants deposited on historical buildings. Int Biodeter Biodegr 40:225-232

Sanmartín P, Cappitelli F (2017) Evaluation of accelerated ageing tests for metallic and non-metallic graffiti paints applied to stone. Coatings 7:180

Sanmartín P, Bosch-Roig P (2019) Biocleaning to remove graffiti: a real possibility? Advances towards a complete protocol of action. Coatings 9:104

Sanmartín P, Pozo-Antonio JS (2020) Weathering of graffiti spray paint on building stones exposed to different types of UV radiation. Constr Build Mater 236:117736

Sanmartín P, Cappitelli F, Mitchell R (2014) Current methods of graffiti removal: a review. Constr Build Mater 71:363-374

Sanmartín P, DeAraujo A, Vasanthakumar A, Mitchell R (2016) Feasibility study involving the search for natural strains of microorganisms capable of degrading graffiti from heritage materials. Int Biodeter Biodegr 103:186-190 
Sanmartín P, Mitchell R, Cappitelli F (2016) Evaluation of cleaning methods for graffiti removal. In: Brimblecombe P (ed) Urban pollution and changes to materials and building surfaces. Imperial College Press, London, pp 291-312

Sanmartín P, DeAraujo A, Vasanthakumar A (2018) Melding the old with the new: trends in methods used to identify, monitor and control microorganisms on cultural heritage materials. Microb Ecol 76:64-80

Shingal N, Kumar M, Kanaujia PK, Virdi JS (2015) MALDI-TOF mass spectrometry: an emerging technology for microbial identification and diagnosis. Front Microbiol 6:791

Siano S, Agresti J, Cacciari I, Ciofini D, Mascalchi M, Osticioli I, Mencaglia AA (2012) Laser cleaning in conservation of stone, metal, and painted artifacts: state of the art and new insights on the use of the Nd:YAG lasers. Appl Phys A Mater Sci Process 106:419-446

Soffitti I, D'Accolti M, Lanzoni L, Volta A, Bisi M, Mazzacane S, Caselli E (2019) The potential use of microorganisms as restorative agents: an update. Sustainability 11:3853

Troiano F, Vicini S, Gioventù E, Lorenzi PF, Improta CM, Cappitelli F (2014) A methodology to select bacteria able to remove synthetic polymers. Polym Degrad Stabil 107:321-327

Turner JN (1967) The microbiology of fabricated materials. J\&A Churchill, London

Vilanova C, Porcar M (2020) Art-omics: multi-omics meet archaeology and art conservation. Microb Biotechnol 13:435-441

Weaver ME (1995) Removing graffiti from historic masonry. Preservation Brief No. 38. National Park Service, Technical Preservation Services, Washington DC

Webster A, May E (2006) Bioremediation of weathered-building stone surfaces. Trends Biotecnol 24:255-260

Open Access This chapter is licensed under the terms of the Creative Commons Attribution 4.0 International License (http://creativecommons.org/licenses/by/4.0/), which permits use, sharing, adaptation, distribution and reproduction in any medium or format, as long as you give appropriate credit to the original author(s) and the source, provide a link to the Creative Commons license and indicate if changes were made.

The images or other third party material in this chapter are included in the chapter's Creative Commons license, unless indicated otherwise in a credit line to the material. If material is not included in the chapter's Creative Commons license and your intended use is not permitted by statutory regulation or exceeds the permitted use, you will need to obtain permission directly from the copyright holder.

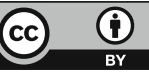

